\title{
OPEN Yoda1 and phosphatidylserine exposure in red cells from patients with sickle cell anaemia
}

\author{
R. Wadud ${ }^{1}$, A. Hannemann ${ }^{1}$, D. C. Rees ${ }^{2}$, J. N. Brewin ${ }^{2}$ \& J. S. Gibson ${ }^{1 凶}$ \\ Phosphatidylserine (PS) exposure is increased in red cells from sickle cell anaemia (SCA) patients. \\ Externalised PS is prothrombotic and attractive to phagocytes and activated endothelial cells and \\ thus contributes to the anaemic and ischaemic complications of SCA. The mechanism of PS exposure \\ remains uncertain but it can follow increased intracellular $\mathrm{Ca}^{2+}$ concentration $\left(\left[\mathrm{Ca}^{2+}\right]_{i}\right)$. Normally, $\left[\mathrm{Ca}^{2+}\right]_{i}$ \\ is maintained at very low levels but in sickle cells, $\mathrm{Ca}^{2+}$ permeability is increased, especially following \\ deoxygenation and sickling, mediated by a pathway sometimes called $\mathrm{P}_{\text {sickle }}$. The molecular identity \\ of $P_{\text {sickle }}$ is also unclear but recent work has implicated the mechanosensitive channel, PIEZO1. We \\ used Yoda1, an PIEZO1 agonist, to investigate its role in sickle cells. Yoda1 caused an increase in $\left[\mathrm{Ca}^{2+}\right]_{\mathrm{i}}$ \\ and PS exposure, which was inhibited by its antagonist Dooku1 and the PIEZO1 inhibitor GsMTx4, \\ consistent with functional PIEZO1. However, PS exposure did not necessitate an increase in $\left[\mathrm{Ca}^{2+}\right]_{i}$. \\ Two PKC inhibitors were also tested, chelerytherine chloride and calphostin C. Both reduced PS \\ exposure whilst chelerytherine chloride also reduced Yoda1-induced increases in $\left[\mathrm{Ca}^{2+}\right]_{i}$. Findings are \\ therefore consistent with the presence of PIEZO1 in sickle cells, able to mediate $\mathrm{Ca}^{2+}$ entry but that \\ PKC was also involved in both $\mathrm{Ca}^{2+}$ entry and PS exposure.
}

As in other cells, the aminophospholipid phosphatidylserine (PS) of red cells is usually located on the inner leaflet of the membrane bilayer. This is important because externalised PS is prothrombotic, and also attractive to macrophages and activated endothelial cells ${ }^{1}$. PS exposure may thus be associated with red cell death and blockage of the microvasculature. Normally less than $1 \%$ red cells are positive for externalised PS. Notwithstanding, increased PS exposure does occur in healthy red cells during their normal ageing process ${ }^{2-4}$. In addition, however, red cells from patients with sickle cell anaemia (SCA) show less PS asymmetry than those from normal individuals, such that a high, but variable, proportion (c.1-10\%), are positive for exposed PS ${ }^{5,6}$. Loss of the asymmetric distribution of this aminophospholipid may thereby contribute to both the chronic anaemia and acute ischaemic episodes characteristic of the morbidity of SCA.

Movement of PS across the red cell membrane is dependent mainly on three transport systems: (i) an ATPdependent aminophospholipid translocase (or flippase) which moves PS from outer to inner leaflet using energy provided by ATP hydrolysis; (ii) a $\mathrm{Ca}^{2+}$-activated scramblase which rapidly moves PS in both directions; and (iii) a floppase which moves PS from inner to outer leaflet ${ }^{7}$. PS exposure requires both inhibition of the flippase together with activation of the scramblase $e^{1,8}$. Both of these may be precipitated by increases in intracellular $\mathrm{Ca}^{2+}$ concentration $\left(\left[\mathrm{Ca}^{2+}\right]_{\mathrm{i}}\right)$ which under normal circumstances is kept at very low levels, around $30 \mathrm{nM}$, in comparison with a free plasma $\mathrm{Ca}^{2+}$ at a concentration some five orders of magnitude higher (at about 1.1-1.2 mM). Maintenance of these low levels of $\left[\mathrm{Ca}^{2+}\right]_{i}$ is dependent upon the activity of a high capacity plasma membrane $\mathrm{Ca}^{2+}$ pump or ATPase (PMCA) coupled with a very low resting permeability to $\mathrm{Ca}^{2+9}$. As well as promoting PS exposure, elevation of $\mathrm{Ca}^{2+}$ is central to a number of other deleterious consequences which compromise red cell survival-including activation of the $\mathrm{Ca}^{2+}$-activated $\mathrm{K}^{+}$channel (or Gárdos channel ${ }^{10}$ ) and of $\mathrm{Ca}^{2+}$-dependent proteases.

Red cells from SCA patients contain a mutated form of $\mathrm{Hb}, \mathrm{HbS}$, instead of the normal adult $\mathrm{HbA}$. In $\mathrm{HbS}$, a single base substitution results in the exchange of glutamic acid by valine at the sixth amino acid residue of the $\beta$ chain ${ }^{11}$. Replacement of this negatively charged amino acid with a neutral one enables neighbouring molecules of deoxygenated $\mathrm{HbS}$ to adhere, forming long, rigid polymers which distort red cell shape, causing the sickling shape change. HbS-containing red cells also have a markedly abnormal cation permeability ${ }^{12,13}$. This is especially true for $\mathrm{K}^{+}$. There are three transport systems, which are either absent from or kept at low activity in red cells from normal individuals, but which are upregulated or abnormally active in sickle cells: the $\mathrm{KCl}$ cotransporter 
(KCC), a deoxygenation-induced cation conductance (sometimes called $\mathrm{P}_{\text {sickle }}$ ) and the $\mathrm{Ca}^{2+}$-activated $\mathrm{K}^{+}$channel or Gárdos channel ${ }^{13}$. These three systems mediate net ion loss, with water following osmotically, thus raising the concentration of intracellular $\mathrm{HbS}$, the abnormal $\mathrm{Hb}$ found in sickle cells. These events are relevant to pathogenesis as the lag time to polymerisation of $\mathrm{HbS}$ upon deoxygenation is highly dependent on its concentration. A lag inversely proportional to $[\mathrm{HbS}]^{15-30}$ is often quoted ${ }^{14}$. Small solute loss through these transporters may therefore markedly encourage sickling and a catalogue of damaging sequelae, contributing to the pathogenesis of SCA.

One of these cation permeablities, $P_{\text {sickle }}$, is particularly significant for PS externalisation. The $P_{\text {sickle }}$ pathway is activated by $\mathrm{HbS}$ deoxygenation, polymerisation and the sickling shape change ${ }^{15}$, and as well as making the cell leaky to univalent cations, it also mediates entry of $\mathrm{Ca}^{2+16}$. If $\left[\mathrm{Ca}^{2+}\right]_{\mathrm{i}}$ approaches a few hundred nanomolar, the co-ordinated inhibition of the flippase and activation of the scramblase is initiated. It is not surprising therefore that deoxygenation of sickle cells has been associated with increase in PS exposure ${ }^{17}$, which are both dependent on the presence of extracellular $\mathrm{Ca}^{2+}$ and which may be inhibited by intracellular $\mathrm{Ca}^{2+}$ chelation ${ }^{3,18}$.

With its proposed central role in SCA pathogenesis, it is understandable that considerable attention has been focused on regulation of $\mathrm{P}_{\text {sickle }}$ and identification of potential therapeutic inhibitors ${ }^{16,19}$. Notwithstanding its significance, however, the molecular identity of $\mathrm{P}_{\text {sickle }}$ still remains uncertain. Various pathways for mediation of $\mathrm{P}_{\text {sickle }}$ activity have been proposed, ranging from a simple disintegrity of the plasma membrane, to specific protein-mediated pathways including VDAC, NMDA receptors, TRPV channels as well as others ${ }^{20}$. Latterly attention has focused on PIEZO1 ${ }^{21}$. PIEZO1 is a very large, multimeric channel with mechanosensitive properties. It is found in many tissues including red cells in which it has been proposed as a $\mathrm{Ca}^{2+}$ channel. There are two compelling pieces of evidence. Thus several ways of distorting the shape of normal red cells, for example shear stress, activate a $\mathrm{Ca}^{2+}$ entry process. In addition, gain-of-function mutations in PIEZO1 have been found in patients with hereditary xerocytosis ${ }^{22-24}$ and stomatocytosis ${ }^{25-27}$ with a proposed mechanism of increased $\mathrm{Ca}^{2+}$ entry causing aberrant Gárdos channel activation and therefore $\mathrm{K}^{+}$loss and dehydration. It is also notable that a common PIEZO1 mutation is present in the African population ${ }^{28}$ although this mutation did not appear to correlate with $\mathrm{P}_{\text {sickle }}$ activity ${ }^{29} . \mathrm{P}_{\text {sickle }}$ has long thought to be unique to red cells from SCA patients, which is odd given that the underlying mutation resides in the $\beta$ globin gene, and not in any a membrane transport protein. Findings with PIEZO1 suggest that a $\mathrm{P}_{\text {sickle }}$ entity may therefore be present and functional in red cells of all people.

Recently, several pharmacological agonists/antagonists of PIEZO1 have been described, including Yoda1, Dookul and Jedi $1^{30-33}$. These reagents are somewhat problematical in that they may not be specific for PIEZO1 and, at least one of them, Yoda1, has been found have effects via other mechanisms, notably changes in protein phosphorylation ${ }^{34}$. Notwithstanding, an obvious approach to investigate the involvement of PIEZO1 as a candidate for $\mathrm{P}_{\text {sickle }}$ was to test them on $\mathrm{Ca}^{2+}$ entry and PS exposure in red cells from SCA patients.

There have also been several reports implicating an important role for protein kinase C (PKC) in red cell PS exposure, possibly via opening of $\mathrm{Ca}^{2+}$ channels, but also possibly through a $\mathrm{Ca}^{2+}$-independent action ${ }^{5,35,36}$. Thus various PKC inhibitors reduce PS exposure, and some, but not all, also reduce $\mathrm{Ca}^{2+}$ entry in normal red cells.

In this report, we investigated the roles of $\mathrm{Ca}^{2+}$, PIEZO1 and PKC in PS exposure in sickle cells using agonists and inhibitors of PIEZO1, $\mathrm{Ca}^{2+}$ ionophores, and PKC antagonists. Results show that the PIEZO1 agonist Yodal stimulated $\mathrm{Ca}^{2+}$ entry and caused PS exposure in almost all red cells from SCA patients. An increase in $\left[\mathrm{Ca}^{2+}\right]_{\mathrm{i}}$, however, was not a pre-requisite for PS exposure. Rather Yodal appeared to act mainly via PKC in a $\mathrm{Ca}^{2+}$-dependent and $\mathrm{Ca}^{2+}$-independent mechanism. These results with PIEZO1 modulators confirm previous reports of the complexity of PS exposure in red cells including sickle cells and emphasise an important caveat that pharmacological reagents are often promiscuous in their effect.

\section{Methods}

Chemicals. Fluorescein isothiocyanate-conjugated lactadherin (LA-FITC) and phalloidin (FITC-phalloidin) came from Haematologic Technologies Inc. (Essex Junction, VT, USA), supplied by Cambridge Bioscience (Cambridge, UK). Anti-glycophorin A-PE from Becton Dickinson Biosciences (CA, USA) came from Enzyme Research Laboratories (Swansea, UK). Bromo-A23187, 4-(2-hydroxyethyl)-1-piperazineethanesulfonic acid (HEPES) and Fluo-4-AM came from Calbiochem (Merck, Darmstadt, Germany). Yoda1, Dooku1 and GsMTx4 were supplied by Tocris Bioscience (Abingdon, UK), Glixx Laboratories Inc (Hopkinton, MA, USA) and AbCam (Cambridge, UK); and AbCam also supplied the PKC inhibitors chelerytherine chloride and calphostin C. All other chemicals were supplied by Sigma-Aldrich Co. (Poole, Dorset, UK).

Sample collection and handling. Blood samples were taken with informed consent from patients homozygous for sickle cell anaemia (SCA), HbSS genotype, using the anticoagulant EDTA. The study was approved by the National Health Service (NHS) National Research Ethics Committee (NREC reference 16/ LO/1309). For some experiments, once routine haematological assays had been completed, discarded and anonymised blood was used. All research was conducted with ethical approval and in accordance with the Helsinki Declaration of 1975, as revised in 2008.

Solutions and red cell preparation. The standard salines, buffered with 4-(2-hydroxyethyl)piperazine1-ethanesulfonic acid (HEPES), were either low $\mathrm{K}^{+}$(LK-HBS) or high $\mathrm{K}^{+}$(HK-HBS). For LK-HBS, saline comprised (in $\mathrm{mM}$ ): $\mathrm{NaCl} 145, \mathrm{KCl} 5, \mathrm{MgCl}_{2}$ 0.15, inosine 10 and HEPES 10, (pH 7.4 at $37^{\circ} \mathrm{C} ; 290 \pm 5 \mathrm{mOsm} \mathrm{kg}^{-1}$ ). For HK-HBS, salines were similar but with $\mathrm{NaCl} 54 \mathrm{mM}$ and $\mathrm{KCl} 90 \mathrm{mM}$. For $\mathrm{Ca}^{2+}$ titration curves, additions of EGTA $(2 \mathrm{mM})$ and concentrations of total $\left[\mathrm{Ca}^{2+}\right]$ of $0,1.35,1.63,1.72,1.81,1.85,1.91$ and $2.00 \mathrm{mM}$ were used to clamp free extracellular $\left[\mathrm{Ca}^{2+}\right]\left(\left[\mathrm{Ca}^{2+}\right]_{\mathrm{o}}\right)$ at $0,0.1,0.2,0.3,0.45,0.6,1$ and $10 \mu \mathrm{M}$, respectively. Where required, red cells were permeabilised to $\mathrm{Ca}^{2+}$ with the ionophore bromo-A23187 (6 $\mu \mathrm{M}$ final). For oxidant challenge, a stock solution of tert-butyl hydroperoxide $(t \mathrm{BHP})$ was made in LK-HBS. Exposed PS was labelled with LA-FITC 
(16 nM) in HK-HBS ( $\mathrm{pH} 7.4$ at room temperature, $\mathrm{RT}$ ) containing $1 \mathrm{mM}$ vanadate (LA-FITC binding buffer). To prepare red cells, whole blood was washed four times in HK-HBS (pH 7.4 at RT) to remove plasma and buffy coat. For experiments in which intracellular $\left[\mathrm{Ca}^{2+}\right]\left(\left[\mathrm{Ca}^{2+}\right]_{\mathrm{i}}\right)$ was manipulated, the final two washes contained, in addition, EGTA $(1 \mathrm{mM})$ to remove any contaminant $\mathrm{Ca}^{2+}$. Red cells were stored on ice until required. Haematocrit (Hct) was measured using Drabkin's reagent.

Measurement of externalised PS using LA-FITC. To promote lipid scrambling, red cells were incubated in HK-HBS $\left(0.5 \% \mathrm{Hct} ; 30 \mathrm{~min}, 37^{\circ} \mathrm{C}\right)$ containing $2 \mathrm{mM} \mathrm{EGTA}$ at various $\left[\mathrm{Ca}^{2+}\right]_{\mathrm{o}} \mathrm{s}$, using bromo-A23187 $(6 \mu \mathrm{M})$ to permeabilise red cells to $\mathrm{Ca}^{2+}$, in the absence or presence of different oxidants or thiol modifiers. The activity of bromo-A23187 was abrogated by adding $0.4 \mathrm{mM} \mathrm{Co}^{2+}$. Red cells were then pelleted and resuspended in HK-HBS containing $1 \mathrm{mM}$ vanadate (pH 7.4 at RT), diluted in LA-FITC binding buffer at $0.01 \% \mathrm{Hct}$, and incubated for $15 \mathrm{~min}$ in the dark at RT. Red cells were next pelleted (10 s at 16,100 g), washed once in HK-HBS, resuspended and kept on ice in the dark until flow cytometry analysis. LA-FITC was detected in the FL1 channel of a BD Accuri C6 flow cytometer using logarithmic gain (as for $\mathrm{CM}-\mathrm{H}_{2}$-DCF fluorescence). The positive fluorescent gate was set using red cells unlabelled with LA-FITC. For each measurement 10,000 events were gated. PS positive cells were defined as all events falling within the preset FSC, SSC and positive fluorescent gates. See ${ }^{18}$ for detailed Methodology.

Measurement of red cell membrane integrity. Red cells were treated with $t \mathrm{BHP}(0-1 \mathrm{mM})$ or Yoda1 in HK-HBS $\left(0.5 \% \mathrm{Hct}, \mathrm{pH} 7.4\right.$ for $20 \mathrm{~min}$ at $\left.37^{\circ} \mathrm{C}\right)$, washed and resuspended in HK-HBS. The fluorophore phalloidin-iFluor 647 was added and washed cells were analysed by flow cytometry. Phalloidin labels intracellular actin found in the red cell cytoskeleton. The presence of positive cells indicates that the plasma membrane has been disrupted to allow entry of phalloidin to the cell interior. A positive signal therefore implies of loss of membrane integrity $\left(\mathrm{cf}^{37}\right)$.

Statistics. Results are presented as means \pm SEM for blood samples of $n$ different individuals. All experiments were carried out on paired samples so that control cells, and those treated with one or more inhibitor, were always carried out at the same time, using cells from the same blood donors. Where appropriate, comparisons were therefore made using 2 -tailed Student's $t$-tests and $\mathrm{p}<0.05$ was considered as significant.

\section{Results}

Yoda1 and intracellular $\mathrm{Ca}^{2+}$. In the presence of extracellular $\mathrm{Ca}^{2+}$, Yodal caused a concentrationdependent elevation in $\left[\mathrm{Ca}^{2+}\right]_{\mathrm{i}}$ (Fig. 1a). This effect became significant at a concentration of $100 \mathrm{nM}(p<0.01)$ whilst $\left[\mathrm{Ca}^{2+}\right]_{\mathrm{i}}$ continued to increase up to the maximum concentration used $(5 \mu \mathrm{M})$. In the absence of extracellular $\mathrm{Ca}^{2+}$, as anticipated, Yoda1 had no effect on $\left[\mathrm{Ca}^{2+}\right]_{\mathrm{i}}$ (Fig. 1). Dooku1, an antagonistic analogue of Yoda1 which probably interferes with the binding of Yodal to its $\operatorname{target}^{31}$, inhibited the Yodal-induced rise in $\left[\mathrm{Ca}^{2+}\right]_{\mathrm{i}}$ abolishing the change at a concentration of $10 \mu \mathrm{M}$ (Fig. 1b). The spider venom GsMTx4 (up to $10 \mu \mathrm{M}$ ), which probably inhibits PIEZO1 through alterations in stress of the lipid bilayer, similarly reduced the stimulatory effect of Yoda1 on elevation of $\left[\mathrm{Ca}^{2+}\right]_{\mathrm{i}}$, although its effect was smaller (Fig. 1c). GsMTx4 also slightly but significantly reduced the resting $\left[\mathrm{Ca}^{2+}\right]_{\mathrm{i}}$ in the absence of Yoda1 which would indicate a constitutively active pathway sensitive to this inhibitor. By contrast, a second analogue of Yoda1, Jedi, was without effect (data not shown). These findings are consistent with a Yodal-induced stimulation of $\mathrm{Ca}^{2+}$ entry across the plasma membrane. As Yoda1, Dooku1 and GsMTx4 are all considered to interact with PIEZO1, these results are compatible with PIEZO1-mediated $\mathrm{Ca}^{2+}$ entry and that the majority of red cells can react to mediate $\mathrm{Ca}^{2+}$ increase.

Yoda1 and phosphatidylserine exposure. In the next series of experiments, the effect of Yoda1 on phosphatidylserine (PS) exposure in red cells from SCA patients was investigated, first in the absence of $\mathrm{Ca}^{2+}$ ionophore. As expected from its effects on $\left[\mathrm{Ca}^{2+}\right]_{\mathrm{I}}$, Yodal treatment resulted in increased PS exposure in the majority (about $80 \%$ ) of the red cell population (Fig. 2) at similar concentrations to those required to mediate elevation in intracellular $\mathrm{Ca}^{2+}$, with a significant increase in PS exposure at a Yodal concentration of $100 \mathrm{nM}$ $(p<0.05)$.

Whilst these findings suggested that $\mathrm{Ca}^{2+}$ entry was directly responsible for the lipid scrambling, there was, however, little, or no, inhibitory effect on Yodal-induced PS exposure when red cells were incubated in $\mathrm{Ca}^{2+}$-free saline (Fig. 2), in which circumstances $\left[\mathrm{Ca}^{2+}\right]_{\mathrm{i}}$ remained at control levels (cf Fig. 1). At concentrations of Yoda $1 \geq 0.5 \mu \mathrm{M}$, PS exposure was identical in the presence or absence of extracellular $\mathrm{Ca}^{2+}$. At lower concentrations, there was a suggestion, albeit non-significant, that the presence of extracellular $\mathrm{Ca}^{2+}$ resulted in higher levels of PS exposure (Fig. 2).

The effect of $\mathrm{Ca}^{2+}$ was investigated in more detail in red cells treated with the ionophore bromo-A23187 $(6 \mu \mathrm{M})$ to clamp $\left[\mathrm{Ca}^{2+}\right]_{\mathrm{i}}$ over a range of concentrations from 0 to $1.0 \mu \mathrm{M}$. Results compared red cells exposed to Yodal at two concentrations, 0.2 and $1.0 \mu \mathrm{M}$ with those incubated in its absence (Fig. 3). Without Yoda1, PS exposure increased as $\left[\mathrm{Ca}^{2+}\right]_{\mathrm{i}}$ was elevated with an $\mathrm{EC}_{50}$ of $0.37 \mu \mathrm{M}$ and with a plateau reached at about $0.45 \mu \mathrm{M}$ at which about $40 \%$ cells were positive for externalised PS, consistent with findings from previous work ${ }^{3,15,34}$. At the lower concentration of Yoda1 $(0.2 \mu \mathrm{M})$, PS exposure was also $\mathrm{Ca}^{2+}$ dependent but the concentration dependence was altered to significantly lower values $\left(\mathrm{EC}_{50} 0.18\right)$. Even in the absence of $\mathrm{Ca}^{2+}$, with $0.2 \mu \mathrm{M}$ Yoda1 PS exposure reached about $20 \%$ ( $p<0.05 \mathrm{cf}$ cells without Yoda1). In addition, almost all cells were positive for external PS with $\mathrm{Ca}^{2+}$ of $\geq 0.5 \mu \mathrm{M}$ (cf about $35 \%$ in the absence of Yodal at the highest $\left[\mathrm{Ca}^{2+}\right]$ tested). With the higher concentration of Yoda1 $(1.0 \mu \mathrm{M})$, PS exposure became $\mathrm{Ca}^{2+}$-independent and all cells were positive for PS over the whole $\mathrm{Ca}^{2+}$ titration, including cells incubated in the absence of $\mathrm{Ca}^{2+}$. 
a

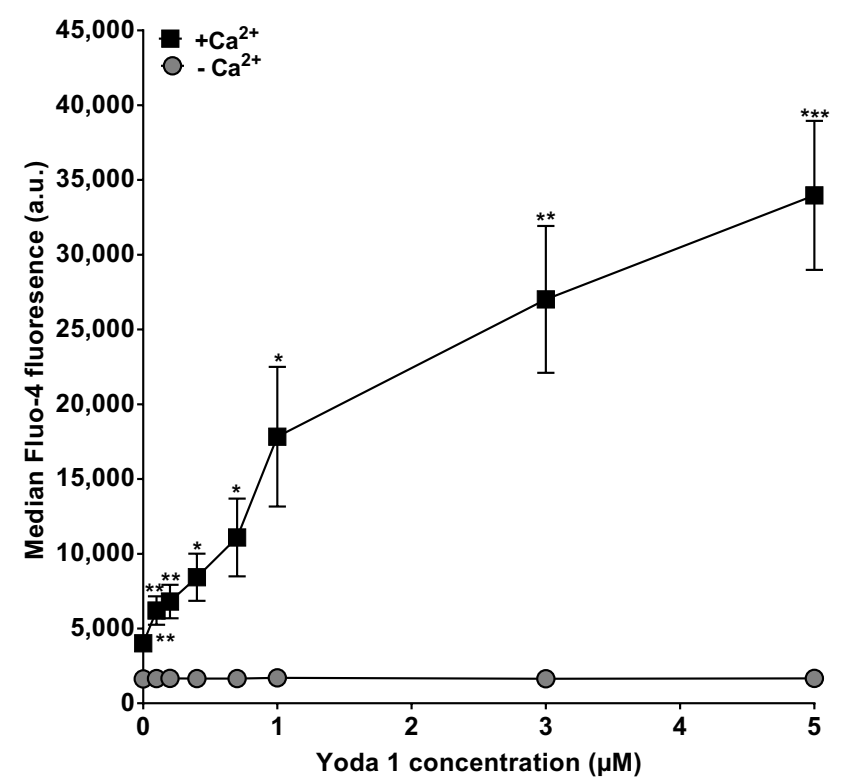

b

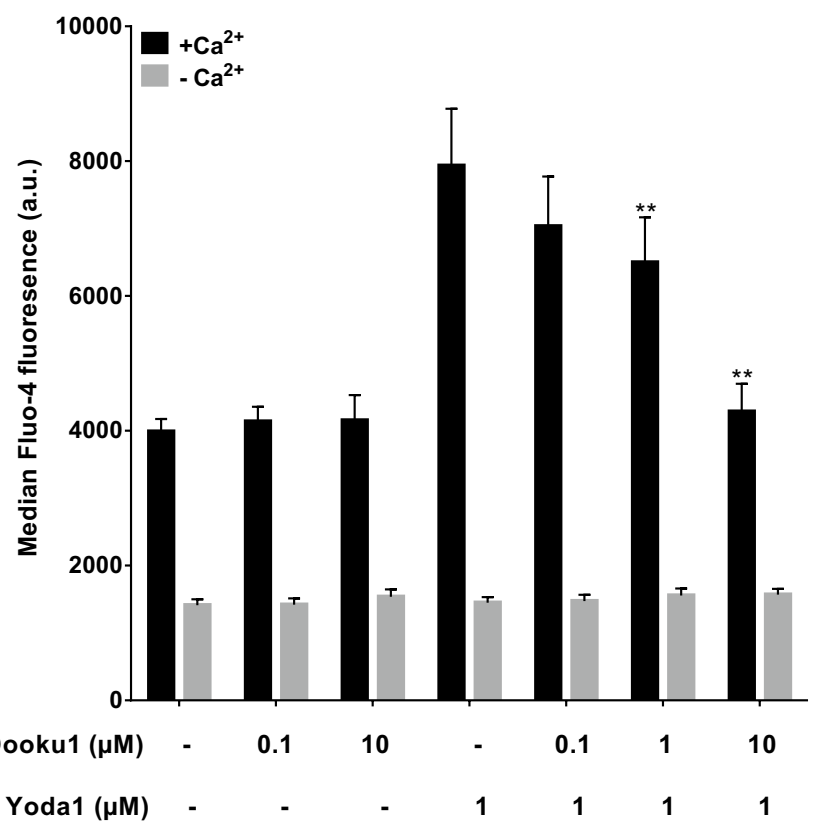

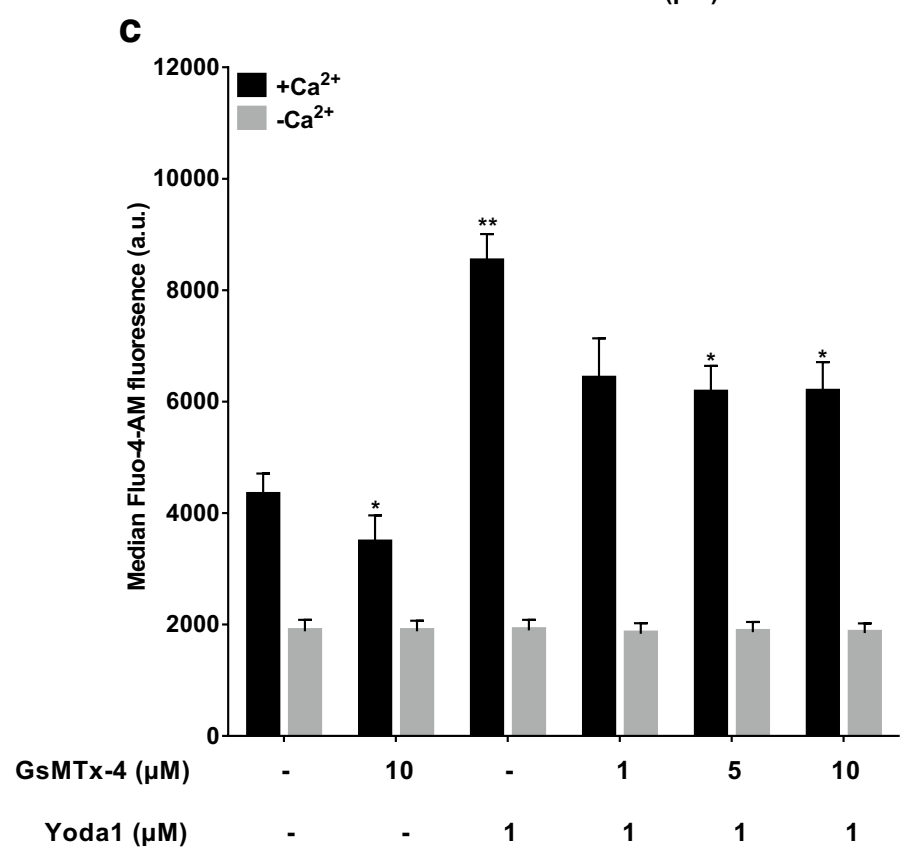

Figure 1. Effect of Yoda1 on intracellular $\mathrm{Ca}^{2+}$ concentration in red cells from patients with sickle cell anaemia (SCA). Red cells $(0.5 \% \mathrm{Hct})$, pre-loaded with Fluo-4-AM $(5 \mu \mathrm{M})$, were equilibrated in air and treated with Yodal $(0.1$ to $5 \mu \mathrm{M})$ for $20 \mathrm{~min}$ at $37^{\circ} \mathrm{C}$ in the absence (EGTA $1 \mathrm{mM}$ and $0 \mathrm{Ca}^{2+}$ ) and presence of extracellular $\mathrm{Ca}^{2+}(1.1 \mathrm{mM})$. Intracellular $\mathrm{Ca}^{2+}$ was measured using Fluo-4. (a) Dose response of Yoda1 in the presence and absence of extracellular $\mathrm{Ca}^{2+}$. ${ }^{* *} p<0.01,{ }^{*} p<0.05$ and ${ }^{* * *} p<0.001$, comparing Red cells treated with Yodal (at $0,0.1,0.2$ and $3 \mu \mathrm{M} ; 0.4,0.7$ and $1 \mu \mathrm{M}$; and $5 \mu \mathrm{M}$, respectively) in the absence and presence of $\mathrm{Ca}^{2+}$. Symbols represent means \pm SEM, $n=4$. (b) Effect of Dookul on Yoda1-induced rise in intracellular $\mathrm{Ca}^{2+}$ concentration. Red cells were pre-incubated with Dookul $(0.1 \mu \mathrm{M}, 1 \mu \mathrm{M}$ and $10 \mu \mathrm{M})$ for $10 \mathrm{~min}$ at $37^{\circ} \mathrm{C}$, following which they were treated with Yoda $1(1 \mu \mathrm{M})$ for a further $20 \mathrm{~min}$ at $37^{\circ} \mathrm{C}$. ${ }^{* *} p<0.01$ comparing red cells in absence of Dookul and its presence. Symbols represent means \pm SEM, $n=5$. (c) Effect of GsMTx4 on Yoda1-induced rise in intracellular $\mathrm{Ca}^{2+}$ concentration. Red cells were pre-incubated with GSMTx $4(1 \mu \mathrm{M}, 5 \mu \mathrm{M}$ and $10 \mu \mathrm{M})$ for $10 \mathrm{~min}$ at $37^{\circ} \mathrm{C}$ following which they were treated with Yoda $1(1 \mu \mathrm{M})$ for a further $20 \mathrm{~min}$ at $37^{\circ} \mathrm{C} .{ }^{*} p<0.05$ and ${ }^{* *} p<0.01$, respectively, comparing either red cells in the presence of Yodal $(1 \mu \mathrm{M})$ alone with those preincubated GsMTx4 $(5 \mu \mathrm{M}$ and $10 \mu \mathrm{M})$ in the presence of extracellular $\mathrm{Ca}^{2+}$, or those treated with DMSO only with those exposed in addition to Yoda $(1 \mu M)$. Histograms represent means \pm SEM, $n=5$. 


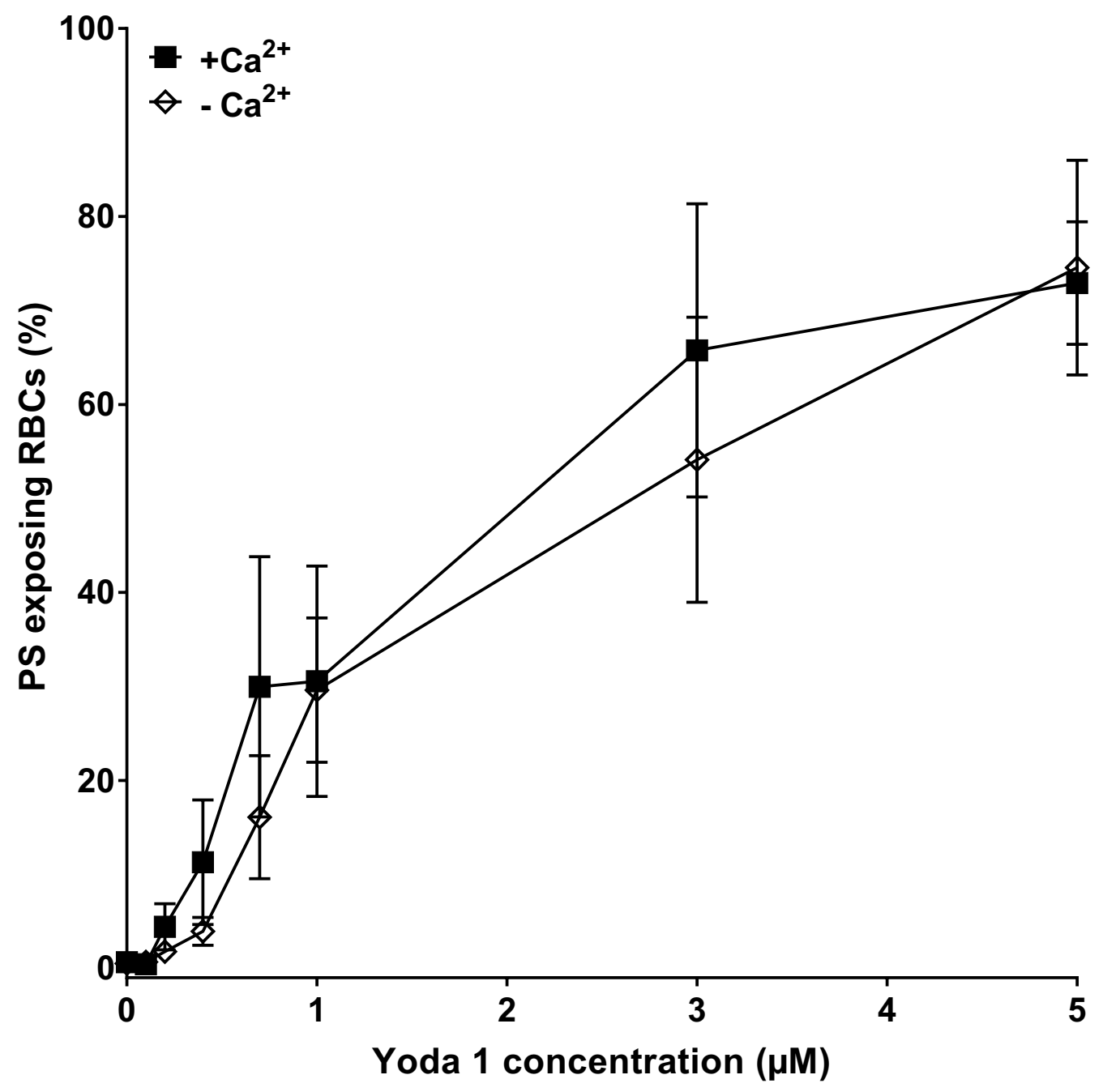

Figure 2. Effect of Yoda1 on phosphatidylserine (PS) exposure in red cells from SCA patients. Red cells $(0.5 \%$ $\mathrm{Hct}$ ) were equilibrated in air with Yodal for $20 \mathrm{~min}$ at $37^{\circ} \mathrm{C}$ in the absence (EGTA $1 \mathrm{mM}$ and $0 \mathrm{Ca}^{2+}$ ) and presence $(1.1 \mathrm{mM})$ of extracelluar $\mathrm{Ca}^{2+}$. They were then labelled with LA-FITC to detect exposed PS using flow cytometry. There was no significant difference in PS exposure without or with extracellular $\mathrm{Ca}^{2+}$. Symbols represent means \pm SEM, $\mathrm{n}=4$.

The effects of Dookul and GsMTx4 on PS exposure were also tested in combination with Yoda1. Results were similar to the findings on intracellular $\mathrm{Ca}^{2+}$ levels. Thus Dookul (up to $10 \mu \mathrm{M}$ ) reduced Yodal-induced PS exposure, in both the presence and absence of $\mathrm{Ca}^{2+}$ (Fig. 4), consistent with its action as a Yoda1 antagonist. In contrast, GsMTx4 (up to $5 \mu \mathrm{M}$ ) had variable effects on PS exposure (data not shown).

Yoda1 and membrane integrity. The above findings showed that Yodal-induced PS labelling was $\mathrm{Ca}^{2+}$-dependent at lower concentrations but, unexpectedly became $\mathrm{Ca}^{2+}$-independent at higher concentrations. One possibility to account for these observations was a breakdown in the lipid bilayer caused by higher Yoda1 concentrations, such that the fluorescent PS label (FITC-lactadherin) had access to phospholipids at both the inner, as well as the outer, leaflet. Results consistent with this hypothesis have been previously obtained using the oxidant tert butyl hydroperoxide ${ }^{37}$. If FITC-lactadherin had been able to access the inside of the lipid bilayer, positively labelled cells would be present in the absence of PS externalisation. To ascertain whether this possibility had occurred, red cells were exposed to fluorescently-labelled phalloidin (phalloidin-iFluor 647) which binds to intracellular actin, but can only gain access to its target if the membrane integrity is disrupted. In a control experiment, as expected, phalloidin-iFluor 647 was unable to label untreated red cells (Fig. 5). Following exposure to the oxidant tert butyl hydroperoxide $(t \mathrm{BHP})$ at concentrations which disrupt the lipid bilayer, red cells stained positively with phalloidin-iFluor 647 due to the membrane damage (Fig. 5a). Yoda1-treated red cells, however, were not labelled with phalloidin-iFluor 647 at concentrations up to $5 \mu \mathrm{M}$ (Fig. $5 \mathrm{~b}$ ), suggesting that the red cell membrane remained intact. 


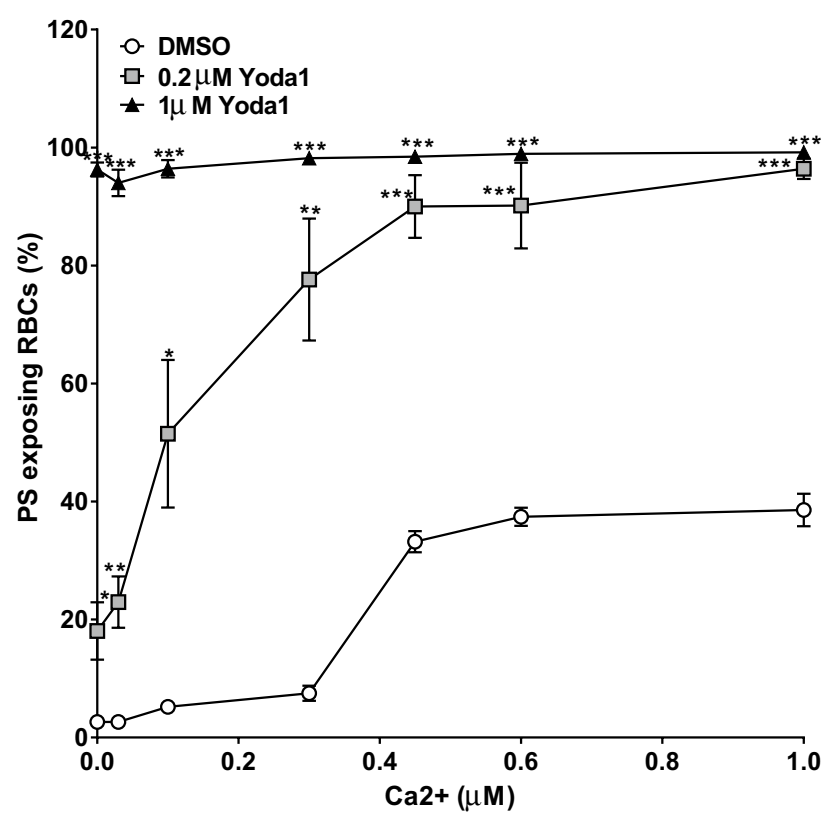

Figure 3. Effect of Yoda 1 and $\mathrm{Ca}^{2+}$ on PS exposure in red cells from SCA patients. Red cells $(0.5 \% \mathrm{Hct})$ were equilibrated in air with Yoda1 $(0.2 \mu \mathrm{M}$ and $1 \mu \mathrm{M})$ at different extracellular $\mathrm{Ca}^{2+}$ concentrations $(0,0.03 \mu \mathrm{M}$, $0.1 \mu \mathrm{M}, 0.3 \mu \mathrm{M}, 0.45 \mu \mathrm{M}, 0.6 \mu \mathrm{M}, 1 \mu \mathrm{M})$ for $30 \mathrm{~min}$ at $37^{\circ} \mathrm{C}$, following which red cell aliquots were removed and exposed PS labelled with LA-FITC. ${ }^{\star} p<0.05,{ }^{* *} p<0.01$ and ${ }^{* * *} \mathrm{p}<0.001$ comparing red cells in the absence and presence of Yodal $(0.2 \mu \mathrm{M})$ at free extracellular $\mathrm{Ca}^{2+}$ s of $0 \mu \mathrm{M}$ and $0.1 \mu \mathrm{M} ; 0.03 \mu \mathrm{M}$ and $0.3 \mu \mathrm{M}$; and $0.45 \mu \mathrm{M}$, $0.6 \mu \mathrm{M}$ and $1 \mu \mathrm{M}$, respectively; $2 \mathrm{mM}$ EGTA). $\mathrm{EC}_{50}$ s for extracellular $\mathrm{Ca}^{2+}$ were $0.37 \mu \mathrm{M}, 0.13 \mu \mathrm{M}$ and $0.18 \mu \mathrm{M}$ for DMSO, $0.2 \mu \mathrm{M}$ and $1 \mu \mathrm{M}$ Yoda1, respectively. Symbols represent means \pm SEM, $n=5$.

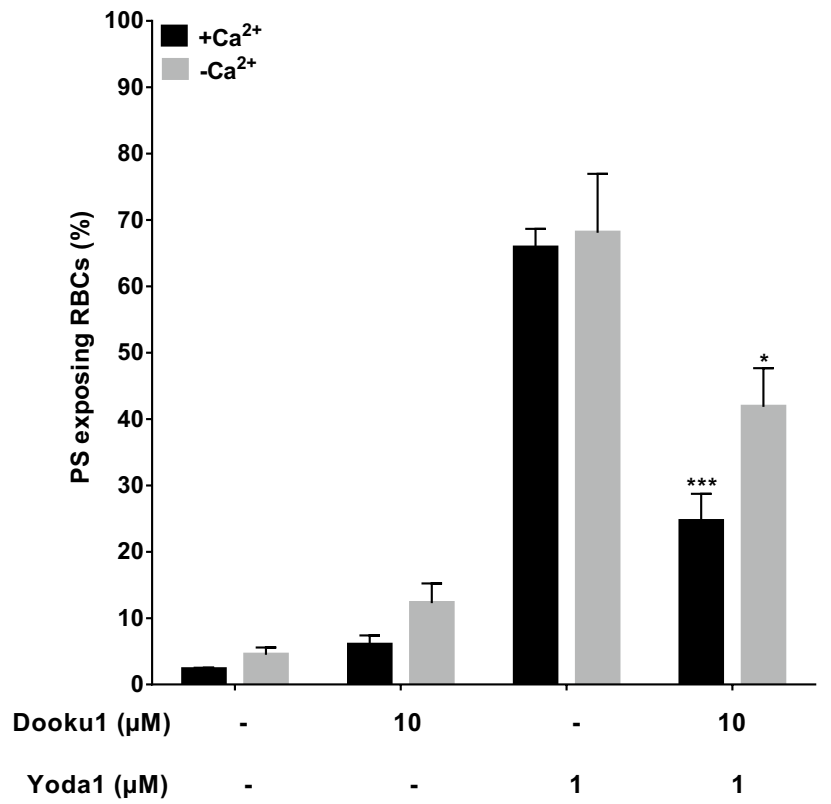

Figure 4. Effect of Dookul on Yoda1-induced PS exposure in red cells from SCA patients. Red cells $(0.5 \% \mathrm{Hct})$ were equilibrated in air in the absence (EGTA $1 \mathrm{mM}$ and $0 \mathrm{Ca}^{2+}$ ) or presence $(1.1 \mathrm{mM})$ of $\mathrm{Ca}^{2+}$. Red cells were initially incubated for 10 min with Dooku $1(10 \mu \mathrm{M})$ and then treated with Yodal $(1 \mu \mathrm{M})$ for a further $30 \mathrm{~min}$, all at $37^{\circ} \mathrm{C}$. Red cell aliquots were then removed and exposed PS labelled with LA-FITC. ${ }^{*} p<0.05$ and ${ }^{* * *} p<0.001$ comparing red cells in the presence of Yodal alone and those pre-incubated Dookul $(10 \mu \mathrm{M})$ in the absence of extracellular $\mathrm{Ca}^{2+}$ or in its presence, respectively. Histograms represent means $\pm \mathrm{SEM}, \mathrm{n}=6$. 


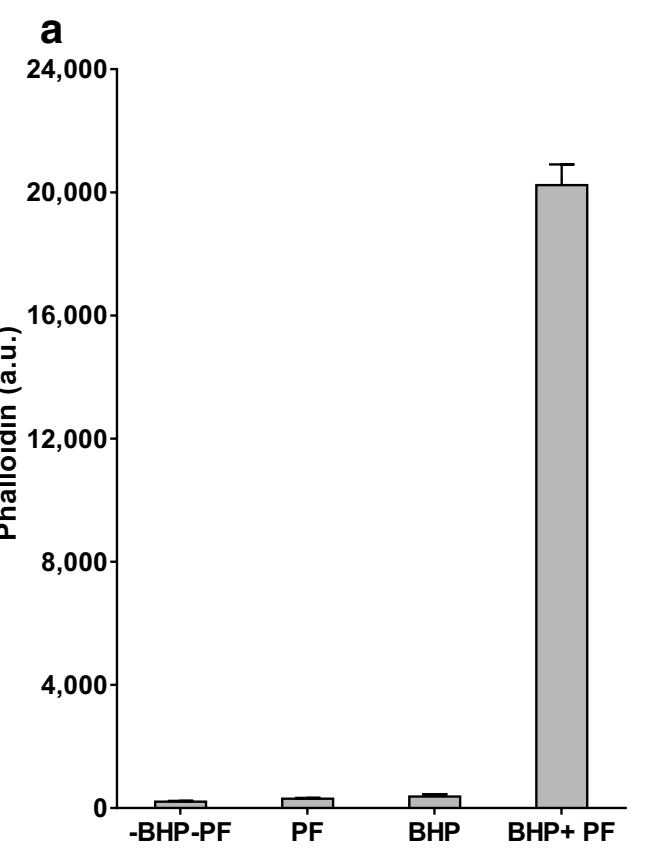

b

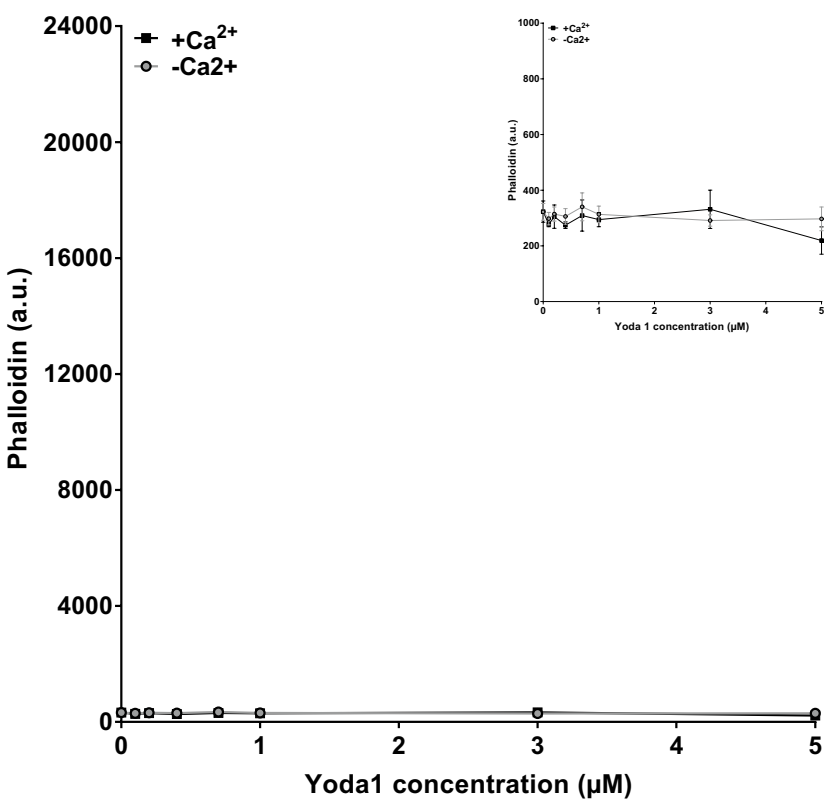

Figure 5. Phalloidin and membrane integrity of red cells from SCA patients. (a) Effect of the oxidant tert butyl hydroperoxide: Red cells were incubated for 20 min without $(-t \mathrm{BHP})$ or with tert butyl hydroperoxide $(+t \mathrm{BHP}$, $0.78 \mathrm{mM})$ and then exposed to phalloidin-iFluor $647(1: 400 ;+\mathrm{PF})$ or left unlabelled $(-\mathrm{PF})$. Phalloidin-iFluor 647 fluorescence is given in arbitrary units (a.u.). Histograms represent means \pm SEM, $n=5$. (b) Effect of Yoda1: Red cells $(0.5 \% \mathrm{Hct})$ were incubated in air for for $20 \mathrm{~min}$ at $37^{\circ} \mathrm{C}$ without or with Yodal (up to $5 \mu \mathrm{M}$ ) in the absence ( $1 \mathrm{mM}$ EGTA and $0 \mathrm{mM} \mathrm{Ca}{ }^{2+} ;-\mathrm{Ca}^{2+}$ ) or presence (extracellular $\mathrm{Ca}^{2+} 1.1 \mathrm{mM} ;+\mathrm{Ca}^{2+}$ ) of extracellular $\mathrm{Ca}^{2+}$. They were then exposed to phalloidin-iFluor 647 (1:400). Phalloidin-iFluor 647 fluorescence is given in arbitrary units (a.u.), detected using flow cytometry using the same scale as Fig. 7a (peak fluorescence 24,000) and also at higher scale (insert, peak fluorescence 1000). The percentage of red cells staining positive ofr phalloidin were $52 \pm 14 \%$ in cells treated with $t \mathrm{BHF}$ and $2-3 \pm 1 \%$ for all other conditions. Symbols represent means $\pm S E M, n=4$.

Yoda1 and protein kinase $C$. From the above, it would therefore appear that Yoda1 did indeed induce PS exposure, but that neither the presence of extracellular $\mathrm{Ca}^{2+}$, nor a rise in intracellular $\left[\mathrm{Ca}^{2+}\right]_{\mathrm{i}}$, were required. Activation of PIEZO1 by Yodal with ensuing $\mathrm{Ca}^{2+}$ influx across the red cell membrane was therefore not a prerequisite for lipid scrambling. Rather there must be some alternative mechanism of action of Yoda1. Previously, Yoda1 has been shown to activate protein kinases in other tissues ${ }^{34}$, and there is also strong evidence of a role for protein kinase C (PKC) in PS exposure ${ }^{2,35,36}$, either via $\mathrm{Ca}^{2+}$ entry through cation channels or via a $\mathrm{Ca}^{2+}$-independent action. The effect of Yoda1 in sickle cells was therefore examined in combination with inhibitors of PKC, chelerytherine chloride which inhibits the active phosphorylation site of PKC, and calphostin C, which is an irreversible inhibitor of the diacylglyceraldehye-binding site.

The effect of chelerethyrine chloride on Yoda1-induced increase in $\left[\mathrm{Ca}^{2+}\right]_{\mathrm{i}}$ is shown in Fig. 6. As before, in the absence of extracellular $\mathrm{Ca}^{2+}$, Yodal $(3 \mu \mathrm{M})$ had no effect on intracellular $\mathrm{Ca}^{2+}$ levels whilst in the presence of extracellular $\mathrm{Ca}^{2+}$, an increase in $\left[\mathrm{Ca}^{2+}\right]_{\mathrm{I}}$ was observed. This rise in $\mathrm{Ca}^{2+}$ was abolished by chelerethyrine chloride $(10 \mu \mathrm{M})$, such that values were unchanged compared to cells incubated in the absence of Yoda1.

When investigating the effect of chelerytherine chloride $(10 \mu \mathrm{M})$ on PS exposure, on its own, this PKC inhibitor had no effect. When combined with Yoda1 $(3 \mu \mathrm{M})$, however, the Yoda1-induced PS exposure was completely inhibited at $1 \mu \mathrm{M}$ Yodal and substantially reduced at $3 \mu \mathrm{M}$ Yodal (Fig. 7a). This figure also shows that the stimulatory effect of Yodal on PS exposure did not require $\mathrm{Ca}^{2+}$.

The effect of chelerytherine chloride on PS exposure on $\mathrm{Ca}^{2+}$-clamped red cells was then investigated (Fig. 7b). At low $\mathrm{Ca}^{2+}$ concentrations, chelerytherine chloride substantially inhibited the Yoda1-induced PS exposure, by about $50 \%$, but inhibition was reduced as the concentration of $\mathrm{Ca}^{2+}$ was increased such that at a $\left[\mathrm{Ca}^{2+}\right]$ of $10 \mu \mathrm{M}$ inhibition was minimal although significant (about $10 \%$ reduction, $\mathrm{p}<0.01$ ). These findings suggest that at low $\mathrm{Ca}^{2+}$ levels Yodal-induced PS exposure is PKC-dependent but that at higher values it becomes PKC-independent.

In the last series of experiments, the effect of a second PKC inhibitor, calphostin C, was investigated. The effect of calphostin C on Yoda1-induced increase in PS exposure was determined (Fig. $7 \mathrm{c}$ ). At lower Yoda1 concentrations $(1 \mu \mathrm{M})$, calphostin $\mathrm{C}(10 \mu \mathrm{M})$ had a large inhibitory effect (about $70 \%, p<0.05)$. Inhibition was still observed at the higher Yodal concentration $(3 \mu \mathrm{M})$ though much reduced (by about $30 \%)$. These findings suggest that Yoda1-induced rise in $\mathrm{Ca}^{2+}$ can be mediated by PKC but that another mechanism is also present, presumably via stimulation of PIEZO1, whilst Yoda1-induced PS exposure, at least at low concentrations of $\mathrm{Ca}^{2+}$, is predominantly via PKC although high $\mathrm{Ca}^{2+}$ causes a PKC-independent PS exposure. 


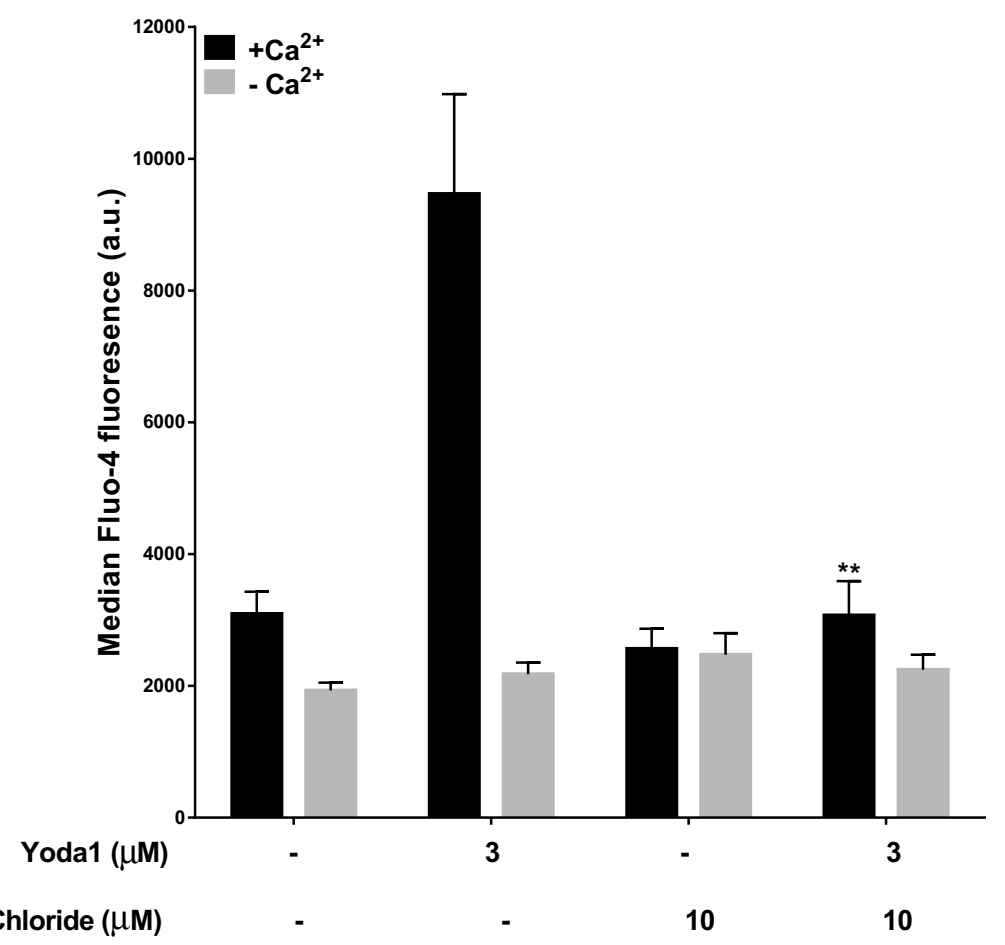

Chelerethyrin Chloride $(\mu \mathrm{M})$

Figure 6. Effect of chelerytherine chloride on Yoda1-induced rise in intracellular $\mathrm{Ca}^{2+}$ concentration in red cells from SCA patients. Red cells $(0.5 \% \mathrm{Hct})$ were equilibrated in air and pre-incubated with chelerethyrin chloride $(10 \mu \mathrm{M})$ for $10 \mathrm{~min}$ following which they were treated with Yodal $(1 \mu \mathrm{M}$ and $3 \mu \mathrm{M})$ for a further $20 \mathrm{~min}$, all at $37^{\circ} \mathrm{C}$, in the absence (EGTA $1 \mathrm{mM}$ and $0 \mathrm{Ca}^{2+}$ ) or presence $(1.1 \mathrm{mM})$ of extracellular Ca $\mathrm{Ca}^{2+}$. Red cell aliquots were then removed and exposed PS labelled with LA-FITC. ${ }^{* *} p<0.01$ comparing red cells in presence of Yoda $1(1 \mu \mathrm{M})$ alone and in combination with pre-incubated chelerythrine chloride $(10 \mu \mathrm{M})$ in the absence $\left(-\mathrm{Ca}^{2+}\right)$ and presence $\left(+\mathrm{Ca}^{2+}\right)$ of $\mathrm{Ca}^{2+}$. Histograms represent means $\pm \mathrm{SEM}, \mathrm{n}=6$.

\section{Discussion}

The effects of Yoda1, a pharmacological activator of PIEZO1, were investigated on intracellular $\left[\mathrm{Ca}^{2+}\right]\left(\left[\mathrm{Ca}^{2+}\right]_{\mathrm{i}}\right)$ and phosphatidylserine (PS) exposure in red cells from patients with sickle cell anaemia (SCA).

Yodal caused a rise in $\left[\mathrm{Ca}^{2+}\right]_{\mathrm{i}}$, dependent on the presence of extracellular $\mathrm{Ca}^{2+}$, consistent with its increased entry across the plasma membrane (Fig. 1a). Findings that the PIEZO1 inhibitors, Dooku1 and GsMTx4, inhibited the elevation in $\left[\mathrm{Ca}^{2+}\right]_{\mathrm{i}}$ were consistent with this mechanosensitive channel being the likely target of Yoda1 for the $\mathrm{Ca}^{2+}$ rise (Figs. 1b,c,3). The majority of red cells responded to Yoda1 implying that most sickle cells express PIEZO1 in their membranes, notwithstanding their stochastic increase in cation permeability in response to deoxygenation and the sickling shape change ${ }^{38}$.

PKC inhibitors, however, also reduced the rise in intracellular $\mathrm{Ca}^{2+}$, making it unlikely that PIEZO1 was the sole, or even the main, target of Yodal and indicating that its pharmacology is more complicated (Figs. 6 and 7 , and text). In the case of PS exposure, Yoda1-induced externalisation occurred in the presence, but also in the complete absence, of extracellular $\mathrm{Ca}^{2+}$, indicating that Yoda1 was able to stimulate PS exposure independent of a rise in $\left[\mathrm{Ca}^{2+}\right]_{\mathrm{I}}$ (Figs. 2 and 7). Notwithstanding that Yodal appears to act additionally via PKC, it clearly can interact with PIEZO1, as shown by patch clamp experiments ${ }^{30}$. It is therefore still possible that it similarly stimulates PIEZO1 in red cells. Whether it does awaits further confirmation in electrophysiological experiments. In addition, it was also noticeable that the extent of PS exposure in response to Yoda1, whilst always present, differed between different red cell samples, indicative of the marked heterogeneous behaviour of sickle cells observed across SCA patients.

Our previous work with the oxidant tert butyl hydroperoxide $(t \mathrm{BHF}$ ) produced a caveat that some reagents can damage the membrane and allow access of the PS label to inside ${ }^{37}$. The highest Yodal concentrations tested, however, did not allow access of fluorescently-labelled phalloidin (phalloidin-iFluor 647). The findings shown in Fig. 5b clearly indicate the lack of permeability to phalloidin-iFluor 647 in Yoda1-treated red cells-there is no fluorescent labelling-whilst phalloidin could gain access following exposure to the oxidant $t$ BHF (Fig. 5b). These findings negated the explanation of disintegrity of the red cell membrane following Yoda1 incubation. The results for PS labelling were not therefore due to Yoda1-induced membrane damage allowing access of FITClactadherin to PS present in the inner leaflet of the RBC membrane bilayer.

With respect to the two inhibitors of protein kinase $\mathrm{C}(\mathrm{PKC})$ tested, chelerytherine chloride reduced the Yoda1-induced increase in $\left[\mathrm{Ca}^{2+}\right]_{\mathrm{i}}$, consistent with Yodal acting also via a PKC-activated cation channel (Fig. 6). Both chelerytherine chloride and calphostin C also reduced Yoda1-induced PS exposure (Fig. 7a,c), also indicating an action partially via PKC. Notwithstanding, inhibition of PS exposure by chelerytherine chloride was 

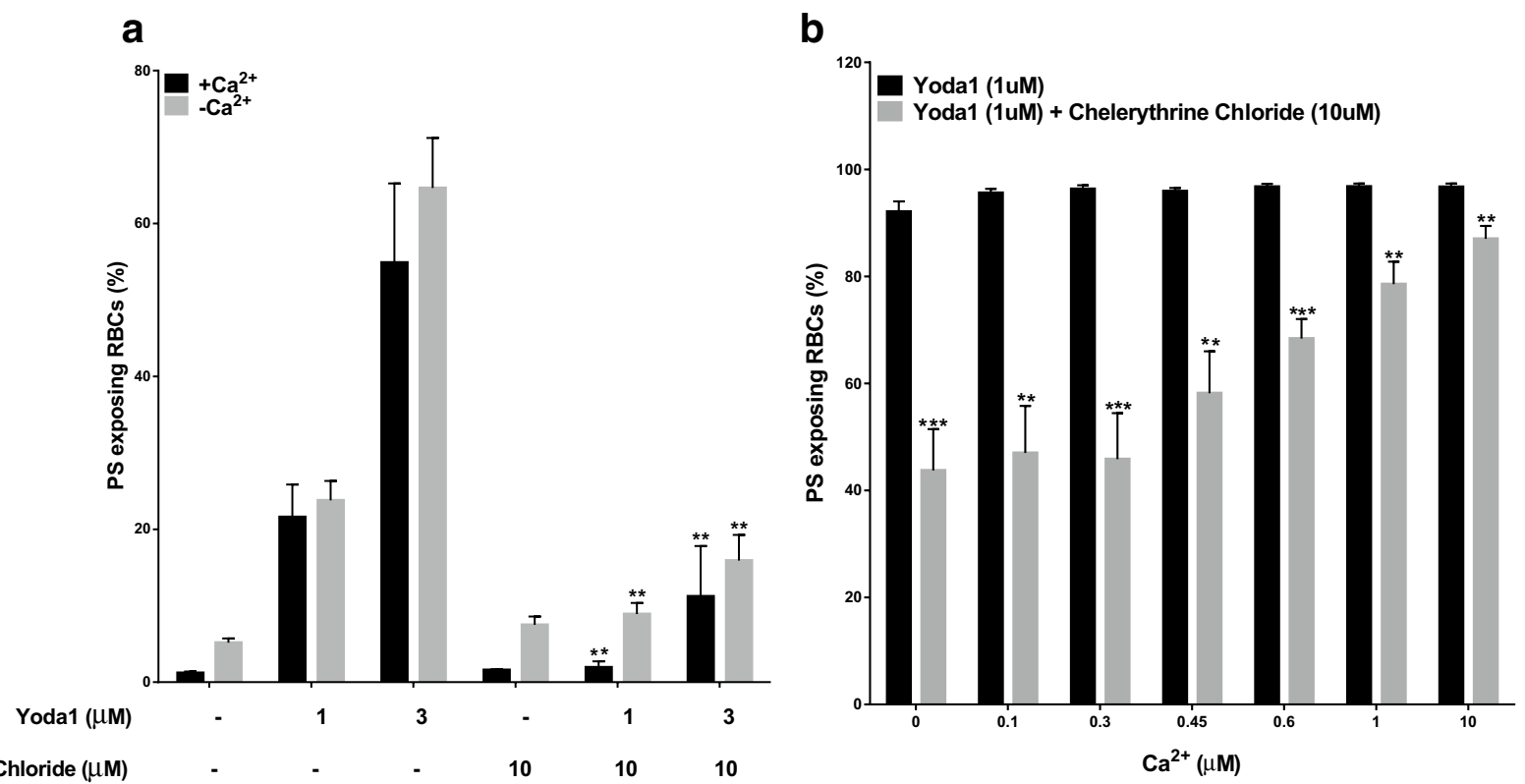

Chelerethyrin Chloride $(\mu \mathrm{M})$

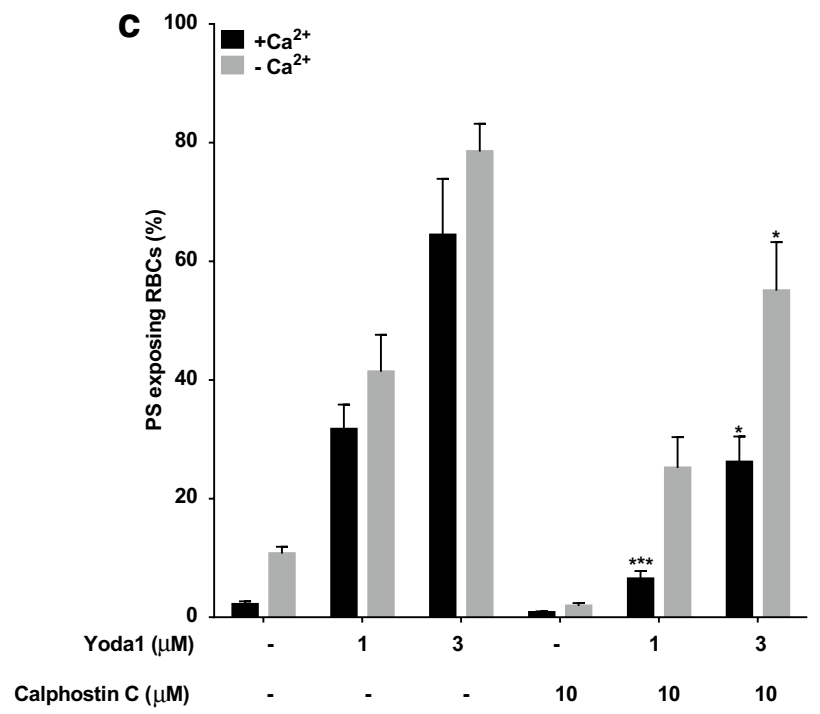

Figure 7. Effect of inhibitors of protein kinase C on PS exposure in red cells from SCA patients. (a) Effect of chelerytherine chloride on Yoda1-induced PS exposure: Red cells $(0.5 \% \mathrm{Hct})$, pre-loaded with Fluo-4AM $(5 \mu \mathrm{M})$, were equilibrated in air and pre-incubated with chelerethyrin chloride $(10 \mu \mathrm{M})$ for 10 min following which they were treated with Yodal $(3 \mu \mathrm{M})$ for $20 \mathrm{~min}$, all at $37^{\circ} \mathrm{C}$, in the absence (EGTA $1 \mathrm{mM}$ and $0 \mathrm{Ca}^{2+}$ ) or presence $(1.1 \mathrm{mM})$ of extracellular $\mathrm{Ca}^{2+} .{ }^{* *} p<0.01$ comparing Red cells in the presence of Yoda1 alone $(3 \mu \mathrm{M})$ and in combination with chelerythrine chloride $(10 \mu \mathrm{M})$. Histograms represent means \pm SEM, $\mathrm{n}=6 .(\mathbf{b})$ Effect of chelerytherine chloride and Yoda1 in $\mathrm{Ca}^{2+}$-clamped Red cells: Red cells $(0.5 \% \mathrm{Hct})$ were equilibrated in air and treated with Yodal $(1 \mu \mathrm{M})$ at different extracellular $\mathrm{Ca}^{2+} \mathrm{s}$ for $30 \mathrm{~min}$ at $37^{\circ} \mathrm{C}$. Red cells $(0.5 \% \mathrm{Hct})$ were equilibrated in air and pre-incubated with chelerythrine chloride $(10 \mu \mathrm{M})$ at different extracellular $\mathrm{Ca}^{2+} \mathrm{s}$ for $10 \mathrm{~min}$, following which they were treated with Yoda1 $(1 \mu \mathrm{M})$ for $20 \mathrm{~min}$, all at $37^{\circ} \mathrm{C}$. Red cells aliquots were then removed and exposed PS labelled with LA-FITC. ${ }^{* *} p<0.001$ and ${ }^{* *} p<0.01$ comparing red cells in the presence of Yodal alone $(1 \mu \mathrm{M})$ and in combination with chelerythrine chloride $(10 \mu \mathrm{M})$ at extracellular $\mathrm{Ca}^{2+}$ s of $0 \mu \mathrm{M}, 0.3 \mu \mathrm{M}$ and $0.6 \mu \mathrm{M}$ and $0.1 \mu \mathrm{M}, 0.45 \mu \mathrm{M}, 1 \mu \mathrm{M}$ and $10 \mu \mathrm{M}$, respectively. Histograms represent means $\pm S E M, n=6$. (c) Effect of calphosin C on Yoda1-induced PS exposure: Red cells $(0.5 \%$ Hct) were equilibrated in air and pre-incubated with calphostin $\mathrm{C}(10 \mu \mathrm{M})$ for $10 \mathrm{~min}$ following which they were treated with Yoda $1(1 \mu \mathrm{M}$ and $3 \mu \mathrm{M})$ for $20 \mathrm{~min}$, all at $37^{\circ} \mathrm{C}$, in the absence (EGTA $1 \mathrm{mM}$ and $0 \mathrm{Ca}^{2+}$ ) or presence $(1.1 \mathrm{mM})$ of extracellular $\mathrm{Ca}^{2+}$. RBC aliquots were then removed and exposed PS labelled with LA-FITC. ${ }^{* * *} p<0.001$ and ${ }^{*} p<0.05$ comparing Red cells in the presence of Yodal alone $(1 \mu \mathrm{M})$ and in combination with calphostin $\mathrm{C}(10 \mu \mathrm{M})$ in the presence $(1.1 \mathrm{mM})$ or absence (EGTA) of extracellular $\mathrm{Ca}^{2+}$, respectively. Histograms represent means \pm SEM, $n=4$. 
attenuated as $\left[\mathrm{Ca}^{2+}\right]_{\mathrm{I}}$ was increased using a $\mathrm{Ca}^{2+}$ ionophore (Fig. $7 \mathrm{~b}$ ), indicating an additional effect of intracellular $\mathrm{Ca}^{2+}$ independent of $\mathrm{PKC}$, although it is also possible that $\mathrm{PKC}$ inhibition used here was incompleteat the concentration of chelerytherine chloride.

Previous work using phorbol myristate acetate (PMA), lysophosphatidic acid (LPA) and the $\mathrm{Ca}^{2+}$ ionophore A23187 together with chelerytherine chloride and calphostin C has also produced evidence for PKC-mediated PS exposure in normal and sickle cells, through both $\mathrm{Ca}^{2+}$-dependent and $\mathrm{Ca}^{2+}$-independent mechanisms ${ }^{2,35,36,39}$. The $\mathrm{Ca}^{2+}$-dependent effect of PKC could be mediated via $\mathrm{Ca}^{2+}$ entry, with the participation of w-agatoxin-TKsensitive, Cav2.1-like, $\mathrm{Ca}^{2+}$ channels or possibly the non-selection cation channel ${ }^{20,40} \cdot \mathrm{Ca}^{2+}$ could act via activation of the scramblase ${ }^{36}$. The present findings using the novel compound, Yoda1, are largely in agreement with these models. They are therefore consistent with Yodal acting as a PKC activator, as well as via PIEZO1 channels.

These previous reports using PMA and $\mathrm{LPA}^{2,35}$ failed to show a clear correlation between red cells with elevations in $\mathrm{Ca}^{2+}$ and PS exposure. They also suggested that PS exposure could not occur in the absence of extracellular $\mathrm{Ca}^{2+2}$, unlike the present findings. There is an important caveat here in that the high $\mathrm{Ca}^{2+}$ affinity of the fluorophores used (fluo3/4) is such that cells would show positive for $\mathrm{Ca}^{2+}$ at low submicrolar concentrations which may be insufficient to cause $\mathrm{Ca}^{2+}$-induced PS scrambling, which occurs at an $\mathrm{EC}_{50}$ of about $1 \mu \mathrm{M}^{6,18,37}$. In addition, variable quenching of the fluorophore, known to be mediated by haemoglobin, may cause cells with similar $\mathrm{Ca}^{2+}$ levels to test negative.

Using Yoda1-induced PS exposure, the present results clearly indicate that this compound can elicit PS exposure in a dose-dependent manner in the complete absence of $\mathrm{Ca}^{2+}$ (Figs. 1, 2 and 3). They show that PKC inhibition prevents Yoda1-induced PS exposure in the absence of $\mathrm{Ca}^{2+}$ and a low $\left[\mathrm{Ca}^{2+}\right]_{\mathrm{i}}$, indicative of mediation via this enzyme. Using $\mathrm{Ca}^{2+}$ clamping with ionophore, they also show that $\mathrm{Ca}^{2+}$ and Yoda1 interact such that Yoda1 shifts the $\mathrm{EC}_{50}$ for $\mathrm{Ca}^{2+}$-induced PS exposure to lower values. Finally, they also show that high $\mathrm{Ca}^{2+}$ can overcome PKC inhibition (Fig. 7b), presumably through direct effects on the scramblase, but probably only at concentrations which would damage the cell in other ways. Notwithstanding, an important limitation of the present work is the use of inhibitors, rather than a molecular approach. Definitive proof of our conclusions must await genetic or molecular studies, perhaps using the CRISPR/Cas9 approach in immortalized red cells precursors.

Taken together the present findings provide further evidence for the dual role of $\mathrm{PKC}$ and $\mathrm{Ca}^{2+}$ in mediation of PS exposure in red cells from SCA patients.

Received: 25 June 2020; Accepted: 1 October 2020

Published online: 18 November 2020

\section{References}

1. Zwaal, R. F. A., Comfurius, P. \& Bevers, E. M. Surface exposure of phosphatidylserine in pathological cells. Cell. Mol. Life Sci. 62, 971-988 (2005).

2. Koshkaryev, A. et al. Non-oxidative band-3 clustering agents cause the externalization of phosphatidylserine on erythrocyte surfaces by a calcium-independent mechanism. Biochim. Biophys. Acta 1862, 183231 (2020).

3. Bernhardt, I., Nguyen, D. B., Wesseling, M. C. \& Kaestner, L. Phosphatidylserine exposure in healthy human erythrocytes and dependence on in vivo cell age. Front. Physiol. 10, 1-10 (2020).

4. Catan, A. et al. Aging and glycation promote erythrocyte phagocytosis by human endothelial cells: Potential impact in atherothrombosis under diabetic conditions. Atherosclerosis 291, 87-98 (2019).

5. de Jong, K., Rettig, M. P., Low, P. S. \& Kuypers, F. A. Protein kinase C activation induces phosphatidylserine exposure on red blood cells. Biochemistry 41, 12562-12567 (2002).

6. Weiss, E. et al. Deoxygenation-induced and $\mathrm{Ca}^{2+}$-dependent phosphatidylserine externalisation in red blood cells from normal individuals and sickle cell patients. Cell Calcium 51, 51-56 (2012).

7. Haest, C. W. M. Distribution and movement of membrane lipids. In Red Cell Membrane Transport in Health and Disease (eds Bernhardt, I. \& Ellory, J. C.) 1-25 (Springer, Berlin, 2003).

8. Kuypers, F. A. Phospholipid asymmetry in health and disease. Curr. Opin. Hematol. 5, 122-131 (1998).

9. Etzion, Z., Fiffert, T., Lew, V. L. \& Bookchin, R. M. Deoxygenation increases $\left[\mathrm{Ca}^{2+}\right]_{\mathrm{I}}$ in sickle cell anemia discocyes by Ca ${ }^{2+}$ pump inhibition as well as increased $\mathrm{Ca}^{2+}$ permeability. Blood 92, 2489-2498 (1992).

10. Gárdos, G. The function of calcium in the potassium permeability of human erythrocytes. Biochim. Biophys. Acta 30, 653-654 (1958).

11. Bunn, H. F. \& Forget, B. G. Hemoglobin: Molecular, Genetic and Clinical Aspects (W. B. Saunders Company, Philadelphia, 1986).

12. Gibson, J. S. \& Ellory, J. C. Membrane transport in sickle cell disease. Blood Cells Mol. Dis. 28, 303-314 (2002).

13. Lew, V. L. \& Bookchin, R. M. Ion transport pathology in the mechanism of sickle cell dehydration. Physiol. Rev. 85, 179-200 (2005).

14. Eaton, J. W. \& Hofrichter, J. Hemoglobin S gelation and sickle cell disease. Blood 70b, 1245-1266 (1987).

15. Mohandas, N., Rossi, M. E. \& Clark, M. R. Association between morphologic distortion of sickle cells and deoxygenation-induced cation permeability increases. Blood 68, 450-454 (1986).

16. Joiner, C. H. Cation transport and volume regulation in sickle red blood cells. Am. J. Physiol. 264, C251-C270 (1993).

17. Blumenfeld, N., Zachowski, A., Galacteros, F., Beuzard, Y. \& Devaux, P. F. Transmembrane mobility of phospholipids in sickle erythrcoytes: Effect of deoxygenation on diffusion and asymmetry. Blood 77, 849-854 (1991).

18. Cytlak, U. M., Hannemann, A., Rees, D. C. \& Gibson, J. S. Identification of the $\mathrm{Ca}^{2+}$ entry pathway involved in deoxygenationinduced phosphatidylserine exposure in red blood cells from patients with sickle cell disease. Pflug. Archiv. Eur. J. Physiol. 465, $1651-1660$ (2013).

19. Ataga, K. I. \& Stocker, J. Senicapoc (ICA-17043): A potential therapy for the prevention and treatment of hemolysis-associated complications in sickle cell anemia. Expert Opin. Investig. Drugs 18, 231-239 (2009).

20. Kaestner, L., Bogdanova, A. \& Egee, S. Calcium channels and calcium-regulated channels in human red blood cells. Adv. Exp. Med. Biol. 1131, 625-648 (2020).

21. Calahan, S. M. et al. Piezo1 links mechanical forces to red blood cell volume. eLife 4, e07370 (2015).

22. Zarychanski, R. et al. Mutations in the mechanotransduction protein PIEZO1 are associated with hereditary xerocytosis. Blood 120, 1908-1915 (2012).

23. Bae, C., Gnanasambandam, R., Nicolai, C., Sachs, F. \& Gottlieb, P. A. Xerocytosis is caused by mutations that alter the kinetics of the mechanosensitive channel PIEZO1. Proc. Natl. Acad. Sci. USA 110, E1162-E1168 (2013).

24. Picard, V. et al. Clinical and biological features in PIEZO1-hereditary xerocytosis and Gardos channelopathy: A retrospective series of 126 patients. Haematologica 104, 1554-1564 (2019). 
25. Andolfo, I. et al. Multiple clinical forms of dehydrated hereditary stomatocytosis arise from mutations in PIEZO1. Blood 212, 3925-3935 (2013).

26. Andolfo, I., Russo, R., Gambale, A. \& Iolascon, A. Hereditary stomatocytosis: An underdiagnosed condition. Am. J. Hematol. 93, 107-121 (2018).

27. Albuisson, J. et al. Dehydrated hereditary stomatocytosis linked to gain-of-function mutations in mechanically activated PIEZO1 ion channels. Nat. Commun. 4, 1884 (2013)

28. Ma, S. et al. Common PIEZO1 allele in African populations causes RBC dehydration and attenuates Plasmodium infection. Cell 173, 443-455 (2018).

29. Rooks, H. et al. A gain of function variant in PIEZO1 (E756del) and sickle cell disease. Haematologica 104, e91 (2019).

30. Syeda, R. et al. Chemical activation of the mechanotransduction channel Piezol. eLife 4, e07369 (2015).

31. Evans, E. L. et al. Yoda1 analogue (Dooku1) which antagonises Yodal-evoked activation of Piezol and aortic relaxation. Br. J. Pharmacol. 175, 1744-1759 (2018).

32. Wang, Y. et al. A lever-like transduction pathway for long-distance chemical- and mechano-gating of the mechanosensitive Piezo1 channel. Nat. Commun. 9, 1300 (2018).

33. Botello-Smith, W. M. et al. A mechanism for the activation of the mechanosensitive Piezol channel by the small molecules Yoda1. Nat. Commun. 10, 4503 (2019).

34. Dela Paz, N. G. \& Frangos, J. A. Yoda1-induced phosphorylation of Akt and ERK1/2 does not require Piezo1 activation. Biochem. Biophys. Res. Commun. 497, 220-225 (2018).

35. Nguyen, D. B. et al. Regulation of phosphatidylserine exposure in red blood cells. Cell. Physiol. Biochem. 28, 847-856 (2011).

36. Wesseling, M. C. et al. Novel insights in the regulation of phopshatidylserine exposure in human red blood cells. Cell. Physiol. Biochem. 39, 1941-1954 (2016).

37. Hannemann, A. et al. Oxidative stress and phosphatidylserine exposure in red cells from patients with sickle cell anaemia. Br. J. Haematol. 182, 567-578 (2018).

38. Lew, V. L. \& Bookchin, R. M. Stochastic nature and red cell population distribution of the sickling-induced Ca ${ }^{2+}$ permeability. J. Clin. Investig. 99, 2727-2735 (1997).

39. Wagner-Britz, L., Wang, J., Kaestner, L. \& Bernhardt, I. Protein kinase Ca and P-type Ca ${ }^{2+}$ channel Ca 2.1 in red blood cell calcium signalling. Cell. Physiol. Biochem. 31, 883-891 (2013).

40. Andrews, D. \& Low, P. S. Role of red blood cells in thrombosis. Curr. Opin. Hematol. 6, 76-82 (1999).

\section{Acknowledgements}

RW was generously supported by a scholarship from Cambridge Commonwealth Trust, and AH, JSG and DCR were gratefully in receipt of a project grant (number 31966) from the British Heart Foundation (BHF).

\section{Author contributions}

J.S.G., A.H. and R.W. planned the study; R.W. and A.H. carried out the experimental work; R.W., J.S.G. and A.H. analysed the data; D.C.R. and J.N.B. collected samples and carried out clinical care; all authors contributed to writing the ms.

\section{Competing interests}

The authors declare no competing interests.

\section{Additional information}

Correspondence and requests for materials should be addressed to J.S.G.

Reprints and permissions information is available at www.nature.com/reprints.

Publisher's note Springer Nature remains neutral with regard to jurisdictional claims in published maps and institutional affiliations.

(c) (i) Open Access This article is licensed under a Creative Commons Attribution 4.0 International License, which permits use, sharing, adaptation, distribution and reproduction in any medium or format, as long as you give appropriate credit to the original author(s) and the source, provide a link to the Creative Commons licence, and indicate if changes were made. The images or other third party material in this article are included in the article's Creative Commons licence, unless indicated otherwise in a credit line to the material. If material is not included in the article's Creative Commons licence and your intended use is not permitted by statutory regulation or exceeds the permitted use, you will need to obtain permission directly from the copyright holder. To view a copy of this licence, visit http://creativecommons.org/licenses/by/4.0/.

(c) The Author(s) 2020 